\title{
Origin, activity and environmental acclimation of stem secondary tissues of the polar willow (Salix polaris) in high-Arctic Spitsbergen
}

\author{
Aleksandra Słupianek ${ }^{1}$ Bronisław Wojtuń ${ }^{2}$ Elżbieta Myśkow ${ }^{1}$ (1)
}

Received: 2 May 2018 / Revised: 1 December 2018 / Accepted: 15 February 2019 / Published online: 8 March 2019

(c) The Author(s) 2019

\begin{abstract}
High Arctic is an intensively explored region in relation to predicted global warming. Its long-term impact is analysed in dwarf-shrubs, such as a widely distributed and pioneering species Salix polaris (polar willow). Understanding the functioning of lateral meristems in these dwarf-shrubs is however limited, affecting interpretation of the data. The presented study focused on the formation and anatomy of the derived secondary tissues in the stems of S. polaris from polar habitats. The entire branches of the polar willow were collected in five vegetation types of tundra located in SW Spitsbergen (Svalbard) and analysed on the series of transverse and longitudinal sections. Our analyses showed that the periderm developed in two or three-year old stems as the secondary protective tissue, and that the multiple epidermis, typical of many willow species, was not formed in S. polaris. The secondary xylem in the polar willow stems showed considerable differences in diameter and length of vessel elements within a single stem. Importantly, the size of the vessel elements differed also depending on the tundra vegetation type. Our findings suggest that the soil moisture was a main factor determining the size of vessels, and that their size was not correlated to the nitrogen supply. Our study thus demonstrated the usefulness of different anatomical features of wood, in above-ground organs, in High Arctic research.
\end{abstract}

Keywords Dwarf shrub · Wood anatomy $\cdot$ Lateral meristem $\cdot$ Tundra vegetation $\cdot$ Svalbard Archipelago

\section{Introduction}

Environmental factors, both climatic (e.g. precipitation and temperature; Wodzicki 2001; Begum et al. 2018) and nonclimatic (e.g. the properties of soil or extreme events; Bräuning et al. 2016; Weil and Brady 2017), strongly influence the functioning and growth of plants. It is clearly visible in shrubs and trees, which are characterised by the presence of secondary growth, resulting in the activity of two lateral meristems i.e., vascular cambium and phellogen, which give rise to secondary conducting and protective tissues, respectively (Evert 2006). Cambium, which arises from procambium and parenchyma cells, forms a continuous cylinder of initial cells in young one- to two-year old organs and gives

Elżbieta Myśkow

elzbieta.myskow@uwr.edu.pl

1 Institute of Experimental Biology, University of Wrocław, Kanonia 6/8, 50-328 Wrocław, Poland

2 Department of Ecology, Biogeochemistry and Environmental Protection, University of Wrocław, Kanonia 6/8, 50-328 Wrocław, Poland rise to secondary xylem and phloem (Larson 1994; Spicer and Groover 2010). The first phellogen originates, from epidermis, subepidermis or the layers located beneath, usually as a continuous cylinder of meristematic cells. Then, phellogen gives rise to phelloderm and phellem (cork) resulting in the formation of secondary protective tissue, called periderm. Subsequently, this first phellogen ceases its activity and is replaced by a new layer of phellogen (Trockenbrodt 1990; Angyalossy et al. 2016). Both lateral meristems strongly react to environmental factors and, therefore fluctuation in the presence and/or intensity of these factors, are recorded in the activity of lateral meristems and concomitantly in the anatomy of the daughter tissues, especially in wood (Begum et al. 2018). Therefore, wood is particularly useful in dendrochronology and dendroecology (Douglass 1941; Eckstein 1972; Fritts 1976; Schweingruber 1996, 2007; Bräuning et al. 2016).

In the last decade, effort to understand the impact of climate warming on the functioning of ecosystems resulted in an increased interest in studying the effects of severe climate conditions on Arctic or high mountains plant growth (e.g. Bär et al. 2006; Liang and Eckstein 2009; Hallinger et al. 
2010; Gärtner-Roer et al. 2013; Li et al. 2016). In the Arctic, the studies are conducted on different species of dwarf shrubs including e.g. Betula nana, Cassiope tetragona, Rhododendron lapponicum and Empetrum nigrum (Blok et al. 2011, 2015; Schweingruber et al. 2013; Büntgen et al. 2015; Li et al. 2016; Iturrate-Garcia et al. 2017; Weijers et al. 2017). In addition, the representatives of the Salix genus such as $S$. arctica (Woodcock and Bradley 1994; Schmidt et al. 2010; Schweingruber et al. 2013), S. lanata (Forbes et al. 2010), S. reticulata (Owczarek 2010), S. pulchra (Blok et al. 2011; Iturrate-Garcia et al. 2017) and $S$. polaris (Owczarek 2010; Buchwal 2014; Owczarek and Opała 2016; Opała-Owczarek et al. 2018; Sandal 2017; Le Moullec et al. 2018) are commonly analysed with the use of dendrochronological methods. Among them, the polar willow (Salix polaris) is of particular importance, as a pioneer species playing a crucial role in colonisation of e.g. deglaciated areas in the high-Arctic. Additionally, in some habitats, together with Saxifraga oppositifolia they are the only vascular plants (Nakatsubo et al. 2010; Węgrzyn and Wietrzyk 2015).

Salix polaris is a representative of woody plants commonly growing across the Arctic including Northern Europe, Kamchatka, Ural mountains, Siberia, Alaska and the Northern Canada. It is a slow-growing, small ( $8 \mathrm{~cm}$ high) deciduous and dioecious dwarf shrub (Aiken et al. 2007). Although the wood anatomy of the genus Salix in the temperate zone is known (Schweingruber 1990; InsideWood 2004-onwards), the detailed structure of the secondary xylem of $S$. polaris is mostly limited to wood of the main root (Buchwal 2014). The below-ground parts of the polar willow are extensively used in dendrochronology, mainly to analyse the variations of widths of annual rings, despite formation of discontinuous or missing growth rings (e.g. Owczarek 2010; Buchwal et al. 2013; Owczarek and Opała 2016; Sandal 2017; Le Moullec et al. 2018). In addition, there are some data on the thickness of the bark of the polar willow (Iturrate-Garcia et al. 2017), but without analysing the formation and functioning of the periderm. However, this knowledge is of particular significance, especially in the High Arctic, characterised by harsh climate conditions, such as low temperature, low precipitation and short growing season (Kwaśniewska and Pereyma 2004; Marsz and Styszyńska 2013).

Due to the commonness of S. polaris across the High Arctic and the fact that it is the only woody plant in some locations (Nakatsubo et al. 2010), this plant species is widely used in dendrochronological studies. Therefore, the activity of secondary meristems should be well understood to be able to observe any modification in anatomy. However, the lack of information about the origin and development of these meristems in S. polaris stems prompted us to analyse: 1. the mechanism of formation of lateral meristems in the stem of this species; and 2. the anatomy of the secondary tissues, especially the secondary xylem of the stem. Additionally, we examined 3. the modifications in the wood anatomy (e.g. dimensions of vessel elements) of polar willows growing in different types of tundra vegetation regarding the fact that increased availability of nitrogen in the ornithocoprophilous type of tundra can affect the growth of the polar willow (Skrzypek et al. 2015). Accordingly, as it is known that the formation and functioning of meristems is affected by severe climate, we hypothesised that: 1 . the specific type of protective tissues i.e. the multiple epidermis is formed in the stems of $S$. polaris as it is characteristic of other willow species, both shrubs and trees (compare Kurczyńska 2002); 2. structure of $S$. polaris secondary xylem of stems is characterised by similar features as in other tundra species; 3 . as nitrogen availability is limited in the Arctic tundra, cambial activity and wood formation is influenced by this ecological factor.

\section{Material and methods}

\section{Sampling design}

The study site was located on the NW side of Hornsund Fjord in Wedel Jarlsberg Land, located in SW Spitsbergen (Svalbard), near the Polish Polar Station $\left(77^{\circ} 00^{\prime} \mathrm{N} ; 1^{\circ} 33^{\prime} \mathrm{E}\right)$. According to Walker et al. (2005), Svalbard belongs to bioclimatic subzone A of the Arctic. This subzone is the coldest part of the Arctic. The southwestern part of Svalbard belongs to the northern arctic-tundra zone. At Hornsund, the polar night lasts 104 days (from October 31 to February 11) and the polar day lasts 117 days (from April 24 to August 18). The climate of Hornsund is characterised by the mean annual air temperature of $-4.3{ }^{\circ} \mathrm{C}$. The warmest month is July with mean air temperature of $+4.4{ }^{\circ} \mathrm{C}$, whereas January $\left(-10.9^{\circ} \mathrm{C}\right)$ is the coldest month. Four thermal seasons are distinguished in Hornsund: the longest (151 days) is winter, from December to April, with the mean temperature of $-10.1^{\circ} \mathrm{C}$. Spring covers May and June (61 days) and is characterised by mean temperature of $-0.5^{\circ} \mathrm{C}$. July and August are the months of summer (62 days) with the mean air temperature of $4.2{ }^{\circ} \mathrm{C}$. The last season, autumn, lasts from September to November (91 days) and the mean temperature is $-2.8^{\circ} \mathrm{C}$. The growing season covers three months, from the beginning of June to the end of August. The mean air temperature in these months are $+1.9,+4.4$ and $+4.1^{\circ} \mathrm{C}$, respectively. The mean annual relative humidity at Hornsund is high, $79.4 \%$. Annual mean precipitation is $434 \mathrm{~mm} /$ year with the extreeme days in August and September (Marsz and Styszyńska 2013).

The study area belongs to the Fuglebekken catchment (Fig. 1a, b) which is characterised by a mosaic of tundra vegetation types driven by soil moisture and influence of little auk (Alle alle) colonies (Skrzypek et al. 2015). The dry and 

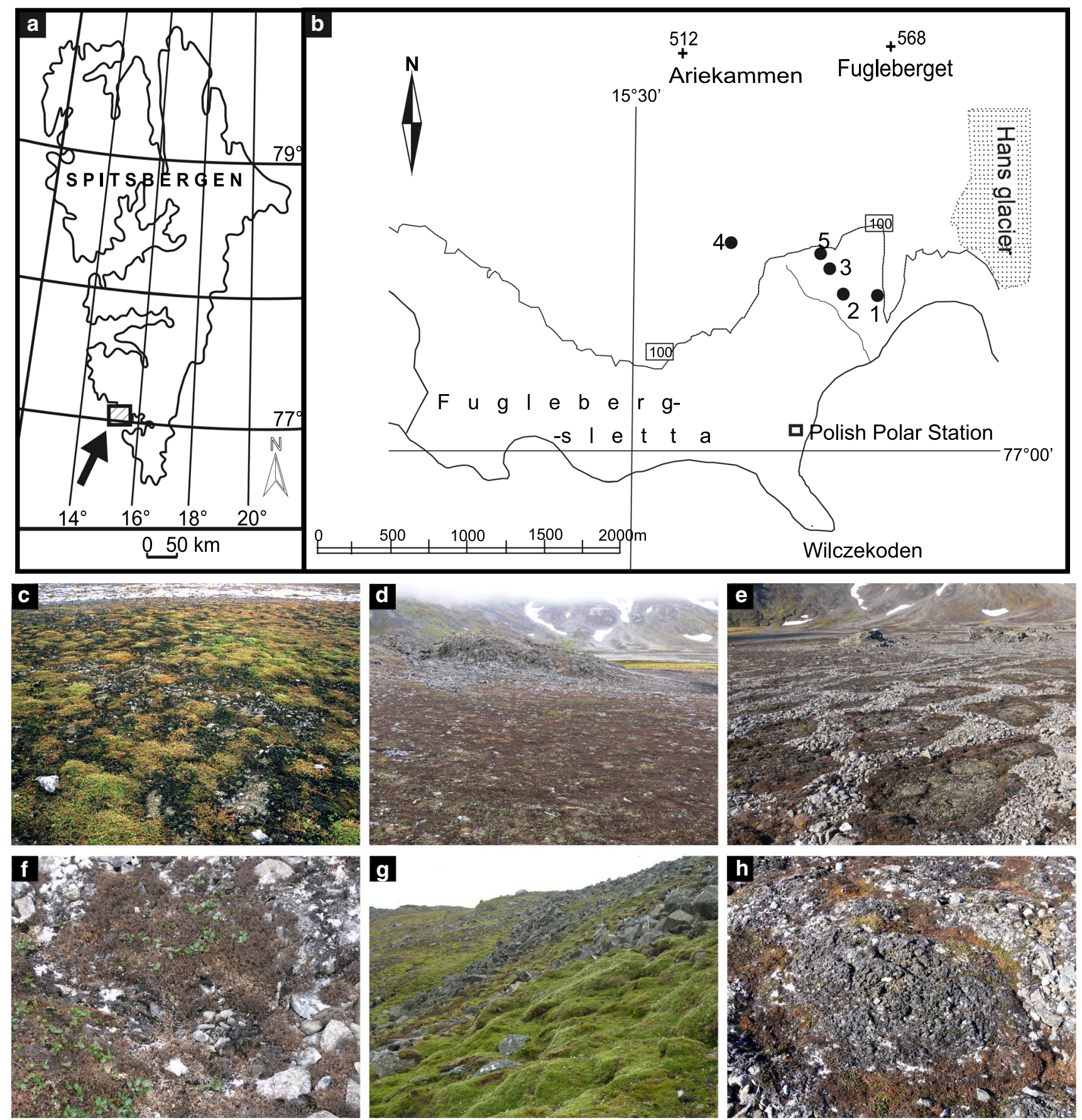

Fig. 1 Map showing study area and sampling locations and pictures of tundra vegetation types. a. The Spitsbergen island. A rectangle and an arrow indicate the area magnified in $\mathbf{b}$. b. Sampling locations; marked by filled dots. Numbers at dots correspond to the tundra vegetation types. c. Medium wet herb-moss tundra, No 1; d Dry lichen-

well-drained habitats of the catchment are vegetated by epigeic moss-lichen tundra and lichen-prostrate shrub tundra. In contrast, permanently moist or wet habitats are vegetated by moss-dominated communities of wet moss tundra. The medium-wet habitats are covered by patterned-ground tundra prostrate shrub tundra, No 2.; e Patterned-ground tundra-the overview of vegetation types Nos 3 and 5; f Dry parts of patterned-ground tundra, No 3; g Medium wet ornithocoprophilous tundra, No 4, Photo D. Richter; $\mathbf{h}$ Medium wet parts of patterned-ground tundra, No 5

and herb-moss tundra. The former is related to areas with dynamic cryogenic processes and micro-relief forms which are composed of fine and moist mineral material surrounded by sorted circles of dry stones. The herb-moss tundra is characterised by the domination of Saxifraga oppositifolia 
tufts and the moss Sanionia uncinata. The sites with high accumulation of seabird faeces are covered by ornithocoprophilous tundra developed on steep slopes. Detailed distribution and properties of soils within the area are described in Szymański et al. (2013) and Migała et al. (2014). Although tundra vegetation of study area as an unglaciated coastal environment, represents only a small fraction of Svalbard's land area (Johansen et al. 2012), selected vegetation types are driven by habitat moisture and influence of little auk colonies. These two ecological factors commonly shape the Arctic vegetation (Ellis 2005; Walker 2010).

The object of the study was Salix polaris Wahlenb., shrub of the Salicaceae family. Its samples were randomly collected in the field during the whole of July 2011, from the independent individuals, growing in a distance of min. $10 \mathrm{~m}$ from one another. To analyse the stem structure, the entire branches of creeping dwarf plants, 20-25 cm long and containing the apices, leaves and the adventitious roots were collected. The material was immediately fixed in the field in formalin-acetic acid-alcohol (FAA) (O'Brien and McCully 1981) for two weeks and then stored in 50\% ethanol.

The plant fragments were sampled from five tundra vegetation types around the Fuglebekken catchment (Fig. 1c-h):

1. Medium wet herb-moss tundra,

2. Dry lichen-prostrate shrub tundra,

3. Dry parts of patterned-ground tundra,

4. Medium wet ornithocoprophilous tundra,

5. Medium wet parts of patterned-ground tundra.

These tundra vegetation types were selected for the study as being representative, both as the commonest and widespread of the study area.

\section{Laboratory methods}

The developmental changes in the structure of stems related to the formation of lateral meristems (cambium and phellogen) and their activity were analysed in ten randomly selected branches, collected from the independent individuals at each tundra vegetation type. Each branch was cut into $0.5 \mathrm{~cm}$ long segments differing in the degree of the maturity of tissues. Transverse hand-made sections, 20-30 $\mu \mathrm{m}$ thick, were prepared using a razor blade, for 7 branches from each tundra vegetation type and observed under a microscope (from $\times 50$ to $\times 500 \mathrm{mag}$ nification) with the bright field and UV light (excitation light $360-370 \mathrm{~nm}$ ) for the anatomy and autofluorescence of cutin and suberin, respectively (Surový et al. 2009; Myśkow 2014). The remaining three branches representing independent individuals in each tundra vegetation type were processed according to the standard protocol for embedding and sectioning in paraffin $\left(\mathrm{O}^{\prime}\right.$ Brien and
McCully 1981). A series of transverse and longitudinal Sects. 8-12 $\mu \mathrm{m}$ thick were cut with the Leica RM 2135 rotary microtome (Leica Instruments $\mathrm{GmbH}$, Wetzlar, Germany), double stained with Alcian blue - Safranin O or Safranin O and Fast green (O'Brien and McCully, 1981), mounted in Euparal and observed under the microscope (from $\times 50$ to $\times 500$ magnification).

The basal parts of four branches from every tundra vegetation type were macerated to analyse the anatomy of the secondary xylem i.e., the shape and type of cells. In this method, plant tissues are treated with chemicals which dissolve the middle lamella, and thus the cells are separated from one another. Therefore, it is possible to analyse the features of individual cells, e.g., lengths of single wood cells, such as vessel elements, parenchyma cells or fibres. To macerate the tissue, the periderm was removed from the branches, the wood was separated from the pith and then cut into smaller pieces. The material was fixed in a mixture of acetic acid and alcohol (1:3) for $24 \mathrm{~h}$ and then boiled in $3 \%$ hydrogen peroxide solution for $4 \mathrm{~h}$. Secondary xylem cells were stained with Alcian blue - Safranin O (O'Brien and McCully, 1981) and observed under a microscope in bright field ( $\times 500$ magnification). The recognition of various types of cells was performed in accordance with the IAWA Committee (1989). Additionally, for each of the five analysed tundra habitats, the length and diameters of 100 randomly chosen vessel elements were measured, using AxioVision Software. The measurements were performed by assignation of the vertical maximal length between both ends of each vessel element. The diameter of the vessel elements was measured at their widest points.

Pictures were taken with an Olympus BX50 epifluorescence microscope using UV emission light (360-370 nm) or in bright field with an Olympus DP71 camera interfaced with Cell B Software (Olympus Optical Co., Warsaw, Poland). Digital images were processed using CorelDRAW 2017.

\section{Statistical analyses}

The lengths and diameters of vessel elements measured for plants from each tundra vegetation type were tested for normality by means of Shapiro-Wilk's W-test and the homogeneity of variances was checked by means of the Brown-Forsythe test (Sokal and Rohlf 2003). The differences in the means of vessel element lengths and diameters between five vegetation types of tundra were compared using one-way parametric ANOVA with Welch's correction (because of unequal variances between groups) and the equal N post-hoc Tukey's test. Data analyses were conducted in Statistica 13 software (StatSoft, Inc. 2014). 


\section{Results}

\section{Primary growth of the stem.}

In all the analysed transverse sections of young fragments of the stems (max. $0.6-0.8 \mathrm{~cm}$ below the apex) only primary tissues were observed (Fig. 2a). The outermost layer was the epidermis composed of one layer of cells with cuticle deposited at its surface (Fig. 2b). Underneath the epidermis, one or two layers distinct of hypodermis consisting of cells with thick and lignified cell walls were observed (Fig. 2b). Further, towards the centre of the cross section, the parenchymatic primary cortex was found and then collateral vascular bundles arranged in a ring (eustele) and located very close to one another (Fig. 2c). Between the primary phloem and xylem, a few procambial cells were clearly visible in vascular bundles (Fig. 2c). The stem centre was filled with parenchymatous pith (Fig. 2a).

\section{Origin and morphology of cambium in the stem}

The earliest signs of cambium formation were visible on the transverse sections acquired approx. $0.6-0.8 \mathrm{~cm}$ below the apex, in all the analysed stems. This distance from the apex corresponded to the parts of the stem formed at the beginning of the current vegetation season, or at the end of the previous season. Periclinal divisions of parenchyma cells, located between vascular bundles and in procambial cells located in vascular bundles, were clearly recognised (Fig. 2d). These resulted in the formation of the continuous cylinder of cambium, visible on the transverse sections at the distance of approx. 1-1.5 cm below the apex. The cambial cylinder was very narrow and consisted of $1-3$ cells in the radial direction (Fig. 2e). The tangential sections of the oldest stems revealed that the arrangement of fusiform initials was nonstoried, meaning that the initials were located in a random manner on the cambial surface (data not shown). The activity of the lateral meristem, manifested in periclinal divisions of initial cells, resulted in the formation of secondary conducting tissues, i.e. xylem and phloem, which were

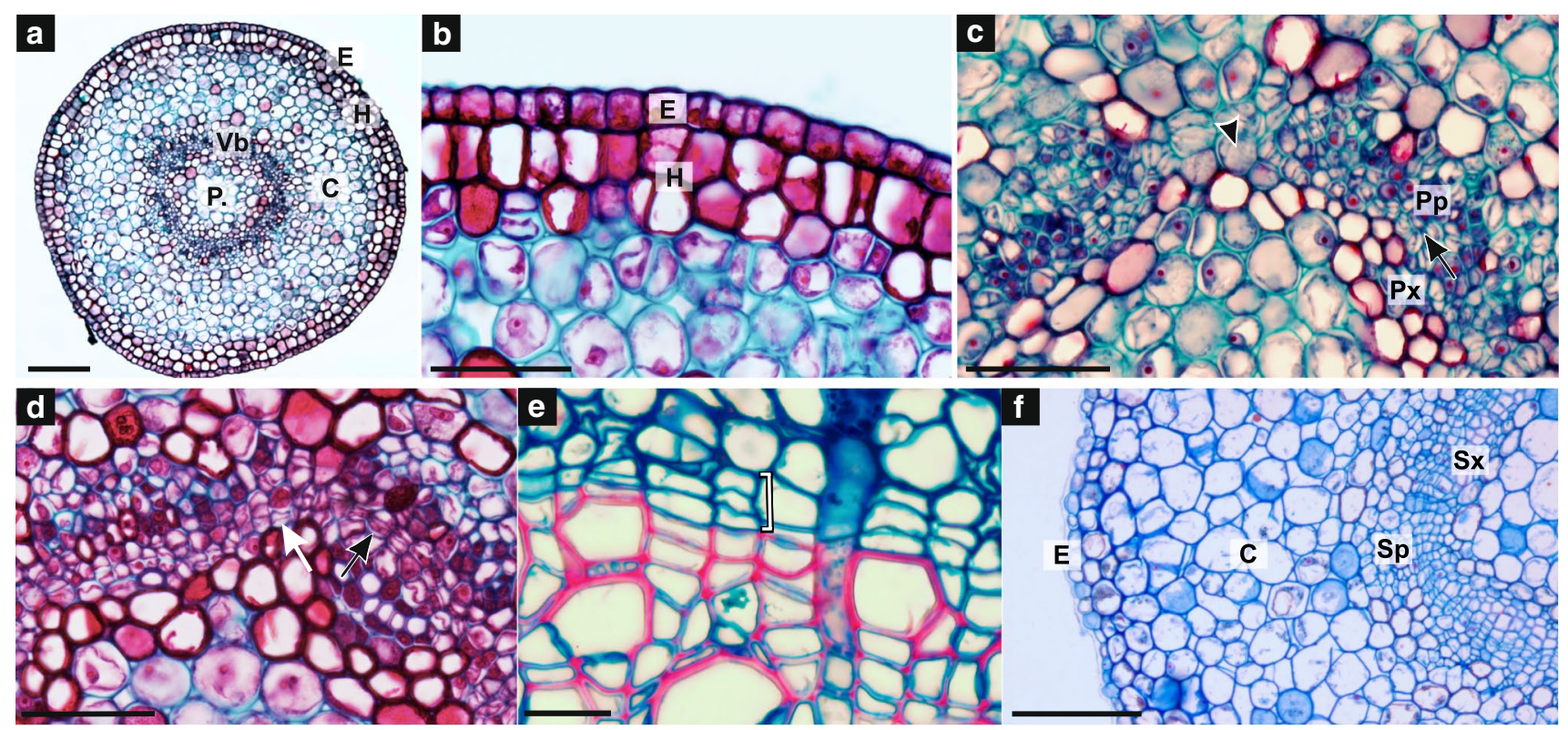

Fig. 2 Anatomy of primary and secondary stems of Salix polaris on transverse sections. a Arrangement of tissues. Epidermis (E), hypodermis $(\mathrm{H})$, parenchyma of primary cortex $(\mathrm{C})$, vascular bundles $(\mathrm{Vb})$ and parenchymatic pith $(\mathrm{P})$, section acquired approx. $0.6 \mathrm{~cm}$ below the apex; b Magnification of single-layer epidermis (E) covered by cuticle. Underneath, two layers of cells with thick and lignified cell walls designated as hypodermis $(\mathrm{H})$, section acquired approx. 0.6 below the apex; c Vascular bundles with primary xylem (Px), primary phloem (Pp) and procambium (arrow); arranged in a ring. Parenchyma cells (arrowhead) between vascular bundles, section acquired approx. $0.7 \mathrm{~cm}$ below the apex; d Origin of cambium. Periclinal divisions of parenchyma cells (white arrow) and procambial cells (black arrow), section acquired approx. $0.8 \mathrm{~cm}$ below the apex; e Two to three cell-thick cambium (bracket), section acquired approx. $1.2 \mathrm{~cm}$ below the apex; f Stem with secondary phloem (Sp) and secondary xylem $(\mathrm{Sx})$ resulting from the activity of cambium. Epidermis (E) and parenchyma in the primary cortex $(\mathrm{C})$ are still present, section acquired approx. $1.6 \mathrm{~cm}$ below the apex. Sections of $S$. polaris from dry parts of patterned-ground tundra, habitat No $3(\mathbf{a}, \mathbf{b})$; medium wet parts of patterned-ground tundra, habitat No 5 (c, d); medium wet ornithocoprophilous tundra, habitat No 4 (e) and medium wet herbmoss tundra, habitat No 1 (f). Scale bars: e $20 \mu \mathrm{m}, \mathbf{b}-\mathbf{d} 50 \mu \mathrm{m}, \mathbf{a}, \mathbf{f}$ $100 \mu \mathrm{m}$ 
found on the transverse sections at $1.6-1.8 \mathrm{~cm}$ below the apex (Fig. 2f).

\section{Secondary xylem of the stems}

The mature wood of polar willow stems was diffuse-porous when analysed on the transverse sections. The annual rings were narrow, approx. $43 \mu \mathrm{m}$ wide, with only 1-2 vessel elements and a limited number of other cells, i.e. fibres, vascular tracheids and axial parenchyma cells formed during the growing season. Such a limited number of cells indicated short cambium activity (Fig. 3a). Additionally, in the transverse sections, the parts of annual rings were discontinuous around the stem circumference. Due to the small number of vascular elements produced and discontinuity of the xylem elements formation, the annual growth rings were hardly distinguishable (Fig. 3a). However, marginally located axial parenchyma cells were present at the annual
Fig. 3 Secondary xylem of Salix polaris stems. aTransverse section. The annual rings are not continuous around stem circumference (denoted by dotted lines and arrowheads). Only 1-2 vessels (V) are formed in the radial direction during the growing season. The flattened cells of terminal parenchyma (arrow) mark the border of the annual growth ring. b Terminal parenchyma cells with characteristic distinct simple pits (arrows) on the tangential section. c Vessels with simple perforation plates (arrows) neighbouring the ray (bracket) on the radial section. d Heterocellular rays with procumbent (black arrow) and upright (white arrow) ray cells on the radial section. Large vessel-ray pits denoted by arrowheads. e Intervessel pits (arrow) shown on the tangential section. $\mathbf{f}$ Macerated vessel elements revealed different shapes. The presence of both short and wide $(1,4)$ and long and narrow $(7,9)$ vessel elements is clearly visible. Here, the vessel elements of $S$. polaris from dry parts of patterned-ground tundra, habitat No 3. are presented. Section of $S$. polaris from medium wet parts of patterned-ground tundra, habitat No 5 (a); dry parts of patterned-ground tundra, location No 3 (b); medium wet herb-moss tundra, location No 1 (c-e). Sections a-e are acquired from the oldest parts of the stems, approx. 13-18 cm below the apex. Scale bars e $20 \mu \mathrm{m}$, b, d $50 \mu \mathrm{m}, \mathbf{a}, \mathbf{c}$ and $\mathbf{f} 100 \mu \mathrm{m}$
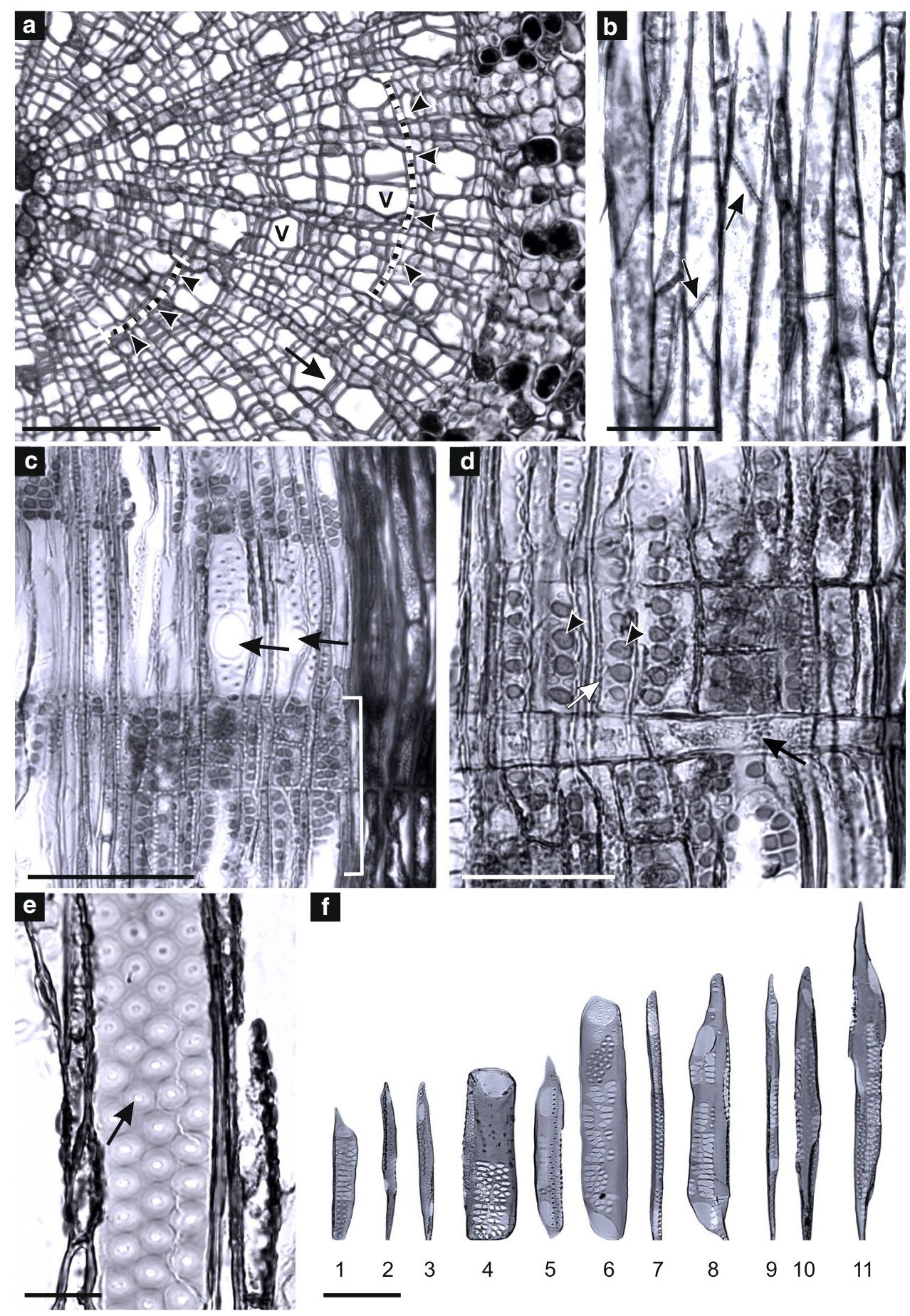

f

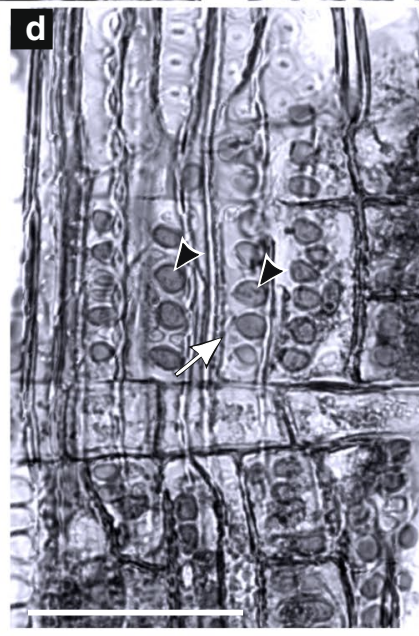

5)
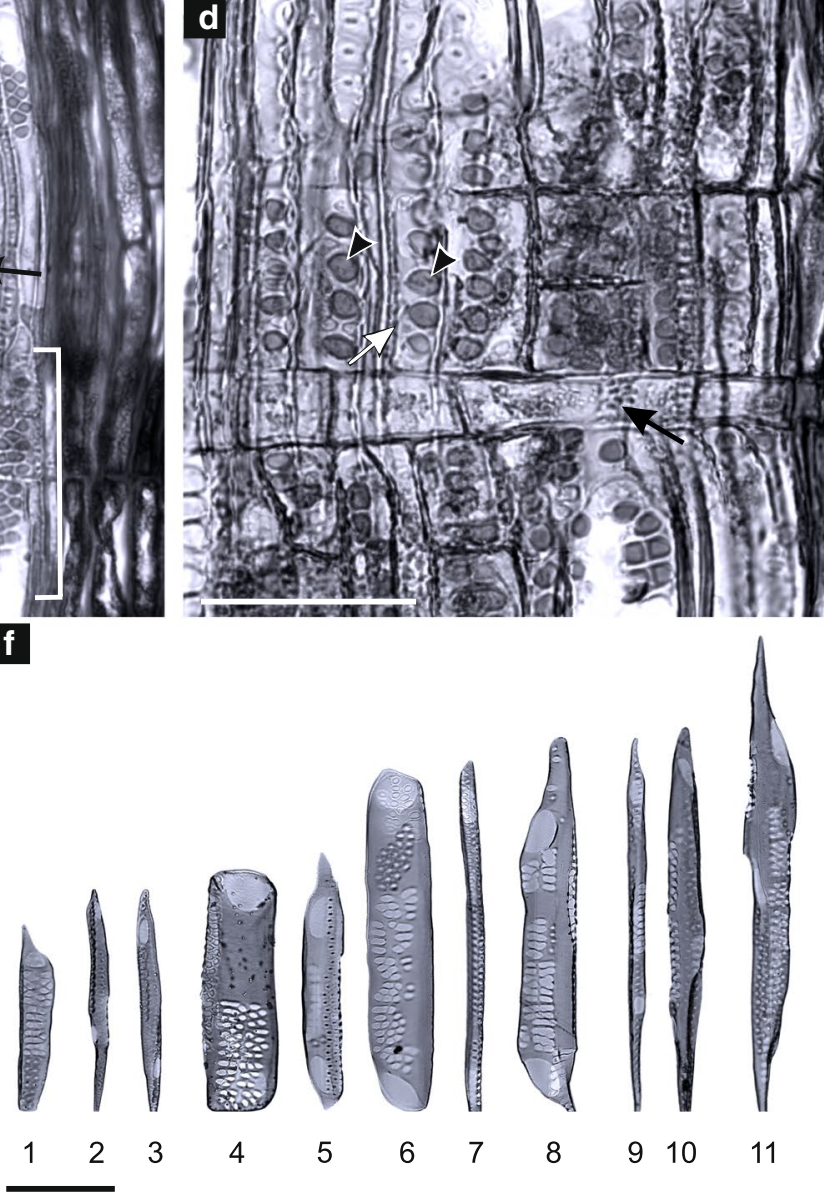
ring border, both on transverse (Fig. 3a) and tangential sections (Fig. 3b), marking the subsequent year increments. The vessel elements of the polar willow were characterised by the presence of simple perforation plates on the radial sections (Fig. 3c) with the alternate type of intervessel pits, which were polygonal in shape as seen on the tangential sections (Fig. 3e). The rays observed on the radial sections were exclusively uniseriate and heterocellular i.e. with two types of cells: procumbent in the centre of the ray and upright at its margins (Fig. 3d). In the marginal cell of the ray, a characteristic feature of the Salix genus, i.e. large vessel-ray pits were observed (Fig. 3d).

As shown before, the developmental changes in the formation and the anatomy of secondary tissues originating from cambium were comparable in all the analysed specimens regardless of the type of tundra vegetation. In addition, the macerates of secondary xylem of polar willow were analysed. The following types of cells were recognised: vessel elements, axial parenchyma cells, vascular tracheids and fibres. In all the analysed branches, representing each of different types of tundra vegetation, large heterogeneity of vessel elements was found (Fig. 3f). Differently shaped, from short and wide to long and narrow vessel elements were found in the macerate, which were composed of all annual rings. However, the latter type of vessel elements was similar to the tracheids except for the presence of perforation plates.

The ranges of vessel element lengths and diameters are presented in Fig. 4. ANOVA proved that there were statistically significant differences in the vessel diameter

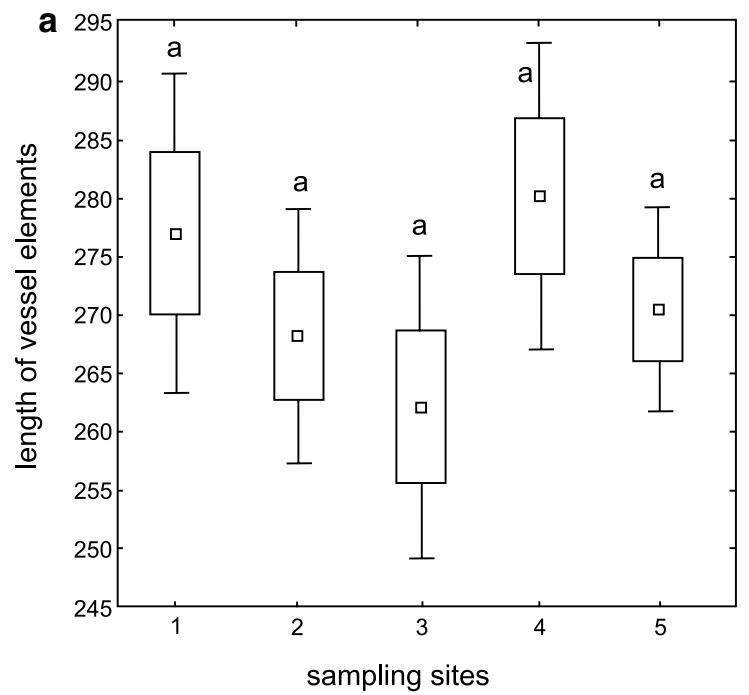

Fig. 4 Comparison of vessel element lengths (a) and vessel element diameters (b) (both in $\mu \mathrm{m}$ ) of Salix polaris growing in five vegetation types of tundra around the Fuglebekken catchment. Mean value and standard error are denoted by small and large boxes, respectively. The Box-Whisker plots show confidential intervals. $n=100$ vessel elements, from all analysed annual rings, for each site. Significant differ-
$\left(F_{4,243.11}=26.77, P<0.0001\right)$ between the sampling sites. There were two homogenous groups of sites: one for No 2 and 3 (dry lichen-prostrate shrub tundra and dry parts of patterned-ground tundra, respectively), and the second for No 1, 4 and 5 (medium wet herb-moss, medium wet ornithocoprophilous and medium wet parts of patternedground types of tundra, respectively). The lowest mean of vessel diameter was found for plants from site No 2 with dry lichen-prostrate shrub tundra. The largest values were measured for plants from site No 4 with medium wet ornithocoprophilous tundra, but they did not differ significantly from the vessel diameter of plants collected in sites No 1 and 5 with medium wet herb-moss and medium wet parts of patterned-ground types of tundra, respectively.

\section{Periderm formation in the stem}

In the stems of the polar willow, when the vascular cambium in stem was already present, the epidermis was replaced by periderm (Fig. 5). The first signs of periderm formation were distinct at a distance of 2.5 to $3 \mathrm{~cm}$ below the apex, referring to two- or three-year old stems. Two parallel periclinal divisions in a few neighbouring epidermal cells (Fig. 5b, c) or occasionally in the subepidermal layer (Fig. 5a) were observed at one side of the stem surface. Meristematic phellogen simultaneously divided periclinally, giving rise to $1-2$ layers of phellem cells (cork) to the outside of the stem, denoted by the distinct autoflourescence of the suberin in their walls (Fig. 5b-e). Only after the formation of two or

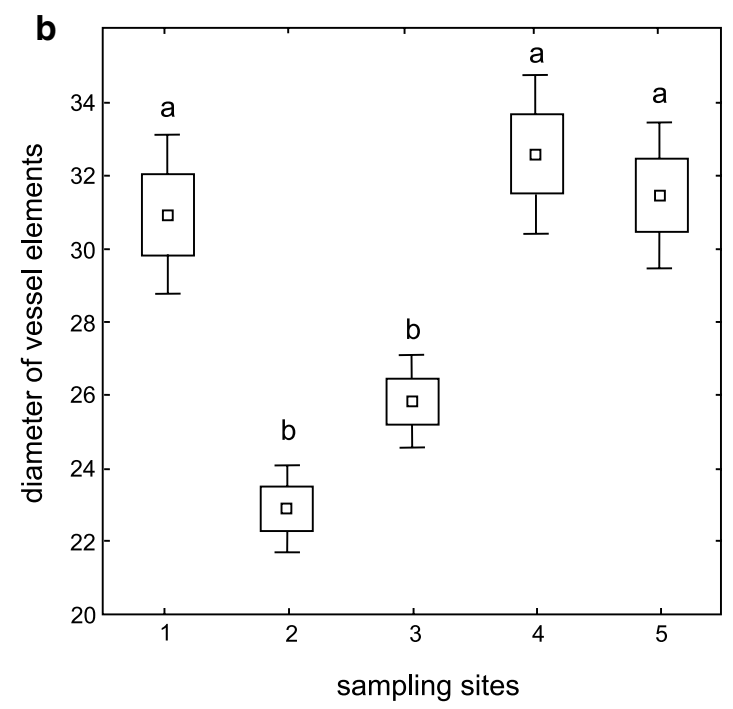

ences are denoted by lower case letters $(P<0.001$, Tukey HSD). The number of the site corresponds to: No 1 -medium wet herb-moss tundra, No 2-dry lichen-prostrate shrub tundra, No 3-dry parts of patterned-ground tundra, No 4-medium wet ornithocoprophilous tundra, No 5-medium wet parts of patterned-ground tundra 
a

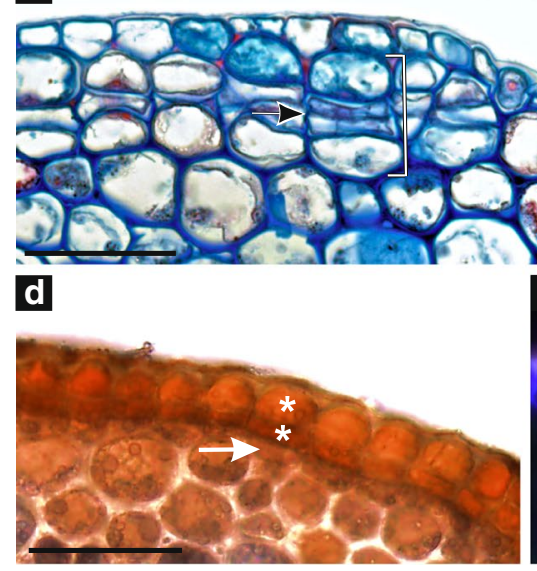

b

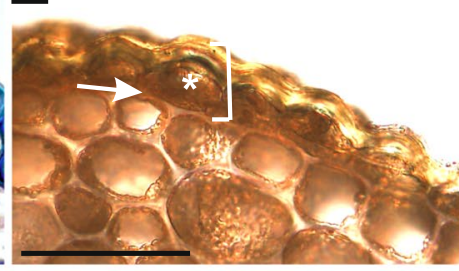

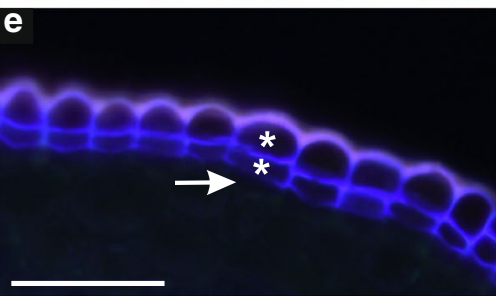

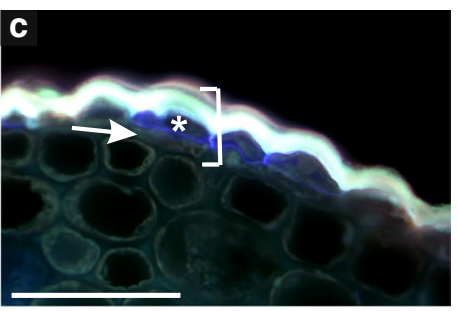

f

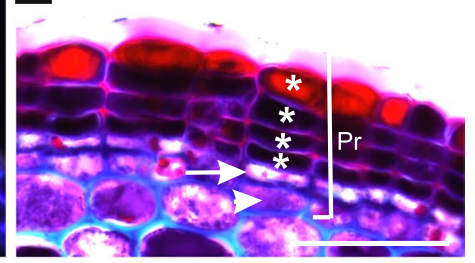

Fig. 5 Periderm of Salix polaris on transverse sections; a Origin of the first phellogen (arrow) resulting of periclinal divisions of subepidermal cells (white bracket). Section acquired approx. $2.5 \mathrm{~cm}$ below the apex; The activity of phellogen (white arrows) results in the formation of phellem cells (stars) shown in bright field (b) and denoted by autofluorescence of suberin under UV light (c). Epidermal cells in which the phellogen was formed are denoted by brackets. Section acquired approx. $2.8 \mathrm{~cm}$ below the apex; A few layers of phellem (stars) formed before phelloderm formation in bright field (d) and denoted by autofluorescence of suberin under UV light (e). Phellogen denoted by arrows. Section acquired approx. $3 \mathrm{~cm}$ below the apex; $\mathbf{f}$ Typical periderm (Pr) consisting of meristematic phellogen (arrow), phellem cells (stars) and phelloderm (arrowhead). Section acquired approx. $5 \mathrm{~cm}$ below the apex. a-c Sections from medium wet ornithocoprophilous tundra, habitat No 4; d-f sections from medium wet parts of patterned-ground tundra, habitat No 5. Scale bars $50 \mu \mathrm{m}$ three cork layers, phellogen produced also cells of parenchymatic phelloderm to the inside of the stem (Fig. 5f). Simultaneously with the formation of phellem and phelloderm, the periclinal divisions leading to the establishment of phellogen cells were also observed in neighbouring epidermal or subepidermal cells. After starting phellogen formation on one side of the stem, the divisions proceeded to neighbouring cells resulting in the formation of a continuous cylinder of phellogen and concomitantly the periderm around the stem at a distance no closer than $5 \mathrm{~cm}$ from the apex.

\section{Discussion}

Contrary to our hypothesis, we have found that protective tissue of S. polaris is formed as typical epidermis composed of one layer of cells. The adaptation of more than 30 species of willows (e.g. S. alba, S. exigua, S. cordata, S. cinerea or $S$. viminalis) to high latitudes with a short growing season is to form multiple epidermis with all layers covered by cuticle. This feature was considered to be characteristic of the genus Salix (Kurczyńska 2002), normally found in several-year-old stems of both trees and shrubs. In these plants the formation of periderm is delayed and enables photosynthesis to occur in stems during the leafless period (Kurczyńska 2002). However, this unique multiple epidermis was not observed in any of the analysed specimens of $S$. polaris and periderm was formed in as young as 2-3-year old stems. It seems possible that in the high-Arctic protection against severe environmental conditions, especially long winter, low temperature and frost, is more important than prolonged photosynthesis. The importance of proper protection in the polar willow was further manifested by the formation of several cork cells before phelloderm, as was earlier postulated for other pioneering species Cornus sanguinea and C. controversa (Myśkow 2014). The high protective value of phellem is related to the deposition of suberin and associated waxes in cell walls and to the programmed cell death of phellem cells. Suberized and dead cells form the barrier, which functions as a layer with properties of an insulated flask between the inside of the plant and the environment. This limits the evaporation of water, the exchange of ions and gases, and protects the willow against the entry of pathogens (Schreiber 2010; Myśkow and Tulik 2014). However, it seems worth monitoring in the future whether the thickness of periderm and timing of its development in S. polaris is not affected, as the decrease in the bark thickness related to global climate warming (IPCC 2014) has recently been observed in three tundra shrubs. In turn, changes in the periderm structure can result in higher vulnerability of plants to pathogens or frost (Iturrate-Garcia et al. 2017). Thus, the further analyses of the structure and functioning of periderm in other woody polar species with reference to different environmental factors seem to be an important direction of the future studies.

Although in stems of $S$. polaris cambium originates similarly as in many woody plants, i.e. from procambium and the parenchyma cells located between vascular bundles (Evert 2006; Myśkow 2010), our results highlight that cambium produces only a small number of conducting elements during the growing season. Moreover, periclinal divisions of 
cambial cells do not occur around the whole circumference of the stem, resulting in discontinuous annual rings. Secondary xylem displays common features of willow wood (Schweingruber 1990; InsideWood 2004-onwards), i.e. diffuse porous wood with uniseriate and heterocellular rays. The terminal layer in the stems is axial parenchyma and not the fibres, although the latter have been previously described in the main root of this species (Buchwal 2014). We also showed the presence of the different types of cells in the secondary xylem of $S$. polaris stem, i.e. vessel elements, vascular tracheids, fibres and axial and ray parenchyma cells. In all the analysed wood fragments the vessel elements, across all annual rings in each stem, markedly differed in size: they were long and narrow with diameters similar to tracheids or even fibres, and thus difficult to distinguish from these types of cells, or they were short with a larger diameter. This specificity of S. polaris wood, and the fact that only one or two vessels are formed during each growing season affect both the identification of the type of cells and establishing the threshold for the measurements of, e.g. the lumen area or density of vessels. In the majority of dendrochronological studies, the narrowest vessels are often below the threshold (and are treated, together with other cells, as a ground tissue) and are not analysed in the conductivity assays, as their role in water conductance is regarded as marginal (von Arx et al. 2012; Gärtner-Roer et al. 2013; Carrer et al. 2015). However, in S. polaris, due to limited number of vessel elements, all of them seem to be indispensable for water transport. However, their role in water conductance requires further analyses. In addition, it would be worth comparing vessel conductance in other polar woody species differing in the secondary xylem structure.

Although the anatomy of secondary xylem in specimens coming from different tundra vegetation types was similar, our results may indicate that the size of vessel elements was probably mostly influenced by habitat moisture and, to a lesser degree, by habitat fertility (Pallardy 2007; Migała et al. 2014; Hacke et al. 2017). Statistically significant differences in vessel diameter were found between the studied tundra types (Fig. 4) with larger diameters in both medium wet herb-moss and ornithocoprophilous tundra vegetation. The differences were also maintained within one habitat type, differing in moisture of microhabitat. Such microhabitats were found in patterned-ground tundra vegetation, characterised by specific micro-relief, i.e. a central part composed of fine and moist mineral material surrounded by sorted circles of dry stones (Skrzypek et al. 2015). The decrease in the diameter of the vessel of the polar willow plants growing in dry tundra vegetation types may be an adaptation to water availability. In dry environment there is a risk of blocked water flow in the conducting elements (vessels) by air bubbles (embolism). The formation of vessels with smaller diameters is thus probably a way to prevent that phenomenon from occurring, although the relationship between the vessel diameter and their vulnerability to embolism is not direct (Carlquist 2012; Marciszewska and Tulik 2013; Hacke et al. 2017). The differences in vessel length between willow plants from five tundra vegetation types are similar in terms of patterns to those of vessel diameter but are of a much smaller magnitude and not statistically significant (Fig. 4).

Low nitrogen availability is the major constraint for plant growth in the Arctic (Atkin 1996; Skrzypek et al. 2015). The content of mineral forms of nitrogen and phosphorus in the soils (all in $\mathrm{mg} \mathrm{kg}$-) of ornitocporophilus (9.0-24.3 N- $\mathrm{NH}_{4}^{+} ; 106.2-285.1 \mathrm{~N}^{+} \mathrm{NO}_{3}{ }^{-} ; 36.6-49.6$ $\mathrm{P}-\mathrm{PO}_{4}{ }^{-)}$and non-ornitocporophilus habitats $(0.17-0.96$ $\left.\mathrm{N}-\mathrm{NH}_{4}{ }^{+} ;<0.005-2.3 \mathrm{~N}-\mathrm{NO}_{3}{ }^{-} ;<0.003-2.3 \mathrm{P}-\mathrm{PO}_{4}{ }^{-}\right)$of the Fuglebekken catchment differed markedly (Richter et al. 2018). Our results indicate that nitrogen might be important for vessel dimensions, since the widest vessel elements were present in the ornitocoprophilus tundra. However, this result was not statistically significant. Our results suggest that the main determining factor responsible for the differences in the final size of vessel elements in polar willow is soil moisture.

Due to global climate changes, the impact of expected warming on development and functioning of plants have become an extensively studied issue. The high-Arctic is of particular importance as predictably the most affected region in terms of, i.e. temperature, precipitation level or the length of growing season (Crawford 2008; Marsz and Styszyńska 2013; IPCC 2014). Climate changes are commonly analysed there in the dwarf-shrubs, including the polar willow, with the use of dendrochronological methods (Forbes et al. 2010; Blok et al. 2011, 2015; Buchwal et al. 2013; Büntgen et al. 2015; Myers-Smith et al. 2015; Li et al. 2016; Iturrate-Garcia et al. 2017; Le Moullec et al. 2018). Our results clearly show that additional analyses, especially of the wood structure in the above-ground parts of shrubs can provide useful data, illustrating i.e., changes in the vessel diameter in relation to the different habitat factors.

\section{Conclusions}

The manuscript presents the development and functioning of the secondary meristems, cambium and phellogen in the above-ground parts of Salix polaris growing in five different tundra habitats. We showed that the periderm developed in 2-3-year-old stems and, in contrary to the majority of willows, the multiple epidermis was never formed. We relate this to the necessity of proper protection of stems in harsh climate conditions of the high-Arctic. Our analyses of the stem wood structure proved that anatomical details can provide additional data showing the impact of the environment 
on secondary xylem formation. We also found the differences in the vessel diameter in the secondary xylem of the polar willow stems in reference to the habitat conditions, mostly moisture and nitrogen availability. However, the latter relationship requires further studies.

Acknowledgements The authors would like to thank three anonymous Reviewers for the extensive revision of the manuscript and very useful comments. We thank Mr. Piotr Paryzek, the professional translator, for English correction and dr. Dorota Richter for sharing the images of tundra. We thank our colleagues from the Department of Plant Developmental Biology, Edyta Gola, Katarzyna Sokołowska, and Alicja Dolzbasz for their helpful support. This study was supported by the University of Wrocław (Grant No. 0401/1068/18/2). Plants were sampled following the Governor of Svalbard permit no. RIS-ID 3704/2011 (issued for BW). The collected plants are not endangered, however, they were sampled on the protected land; therefore, these research permits were obtained.

\section{Compliance with ethical standards}

Conflicts of interest The authors declare no conflict of interest.

Ethical approval This article does not contain any studies with human participants or animals performed by any of the authors.

Open Access This article is distributed under the terms of the Creative Commons Attribution 4.0 International License (http://creativeco mmons.org/licenses/by/4.0/), which permits unrestricted use, distribution, and reproduction in any medium, provided you give appropriate credit to the original author(s) and the source, provide a link to the Creative Commons license, and indicate if changes were made.

\section{References}

Aiken SG, Dallwitz MJ, Consaul LL, McJannet CL, Boles RL, Argus GW, Gillett JM, Scott PJ, Elven R, LeBlanc MC, Gillespie LJ, Brysting AK, Solstad H, Harris JG (2007) Flora of the Canadian Arctic Archipelago: Descriptions, Illustrations, Identification, and Information Retrieval. NRC Research Press, National Research Council of Canada, Ottawa. https://nature.ca/aaflora/ data. Accessed 24 Feb 2017

Angyalossy V, Pace MR, Evert RF, Marcati CR, Oskolski AA, Terrazas T, Kotina E, Lens F, Mazzoni-Viveiros SC, Angeles G, Machado SR, Crivellaro A, Rao KS, Junikka L, Nikolaeva N, Baas P (2016) IAWA list of microscopic bark features. IAWA J 37:517-615. https://doi.org/10.1163/22941932-20160151

Atkin OK (1996) Reassessing the nitrogen relations of Arctic plants: a mini-review. Plant Cell Environ 19:695-704. https://doi. org/10.1111/j.1365-3040.1996.tb00404.x

Bär A, Bräuning A, Löffler J (2006) Dendroecology of dwarf shrubs in the high mountains of Norway-a methodological approach. Dendrochronologia 24:17-27. https://doi.org/10.1016/j.dendr o.2006.05.001

Begum S, Kudo K, Rahman MdH, Nakaba S, Yamagishi Y, Nabeshima E, Nugroho WD, Oribe Y, Kitin P, Jin H-O, Funada R (2018) Climate change and the regulation of wood formation in trees by temperature. Trees 32:3-15. https://doi.org/10.1007/s0046 8-017-1587-6
Blok D, Sass-Klaassen U, Schaepman-Strub G, Heijmans MMPD, Sauren P, Berendse F (2011) What are the main climate drivers for shrub growth in Northeastern Siberian tundra? Biogeosciences 8:1169-1179. https://doi.org/10.5194/bg-8-1169-2011

Blok D, Weijers S, Welker JM, Cooper EJ, Michelsen A, Löffler J, Elberling B (2015) Deepened winter snow increases stem growth and alters stem $\delta^{13} \mathrm{C}$ and $\delta^{15} \mathrm{~N}$ in evergreen dwarf shrub Cassiope tetragona in high-arctic Svalbard tundra. Environ Res Lett 10:044008. https://doi.org/10.1088/1748-9326/10/4/044008

Bräuning A, De Ridder M, Zafirov N, García-González I, Dimitrov DP, Gärtner H (2016) Tree-ring features: Indicators of extreme event impacts. IAWA J 37:206-131. https://doi.org/10.1163/22941 932-20160131

Buchwal A (2014) Constraints on dendrochronological dating of Salix polaris from central Spitsbergen. Czech Polar Rep 4:73-79. https ://doi.org/10.5817/CPR2014-1-8

Buchwal A, Rachlewicz G, Foni P, Cherubini P, Gärtner H (2013) Temperature modulates intra-plant growth of Salix polaris from a high Arctic site (Svalbard). Polar Biol 36:1305-1318. https:// doi.org/10.1007/s00300-013-1349-x

Büntgen U, Hellmann L, Tegel W, Normand S, Myers-Smith I, Kirdyanov AV, Nievergelt D, Schweingruber FH (2015) Temperatureinduced recruitment pulses of Arctic dwarf shrub communities. J Ecol 103:489-501. https://doi.org/10.1111/1365-2745.12361

Carlquist S (2012) How wood evolves: a new synthesis. Botany 90:901-940. https://doi.org/10.1139/b2012-048

Carrer M, von Arx G, Castagneri D, Petit G (2015) Distilling allometric and environmental information from time series of conduit size: the standarization issue and its relationship to tree hydraulic architecture. Tree Physiol 35:27-33. https://doi.org/10.1093/treep hys/tpu108

Committee IAWA (1989) IAWA list of microscopic features for hardwood identification. IAWA Bull 10:219-332

Crawford RMM (2008) Cold climate plants in warmer world. Plant Ecol Divers 1:285-297. https://doi.org/10.1080/1755087080 2407332

Douglass AE (1941) Crossdating in dendrochronology. J For 39:825831. https://doi.org/10.1093/jof/39.10.825

Eckstein D (1972) Tree-ring research in Europe. Tree-ring Bull $32: 1-18$

Ellis JC (2005) Marine birds on land: a review of plant biomass, species richness, and community composition in seabird colonies. Plant Ecol 181:227-241. https://doi.org/10.1007/s11258-005-7147-y

Evert RF (2006) Esau's plant anatomy. Meristems, cells, and tissues of the plant body-their structure, function, and development. Wiley, Hoboken

Forbes BC, Fauria MM, Zetterberg P (2010) Russian Arctic warming and 'greening' are closely tracked by tundra shrub willows. Glob Change Biol 16:1542-1554. https://doi.org/10.111 $1 / \mathrm{j} .1365-2486.2009 .02047 . x$

Fritts HC (1976) Tree rings and climate. Academic Press, London

Gärtner-Roer I, Heinrich I, Gärtner H (2013) Wood anatomical analysis of Swiss willow (Salix helvetica) shrubs growing on creeping mountain permafrost. Dendrochronologia 31:97-104. https://doi. org/10.1016/j.dendro.2012.09.003

Hacke UG, Spicer R, Schreiber SG, Plavcová L (2017) An ecophysiological and developmental perspective on variation in vessel diameter. Plant Cell Environ 40:831-845. https://doi.org/10.1111/ pce. 12777

Hallinger M, Manthey M, Wilmking M (2010) Establishing a missing link: warm summers and winter snow cover promote shrub expansion into alpine tundra in Scandinavia. New Phytol 186:890-899. https://doi.org/10.1111/j.1469-8137.2010.03223.x

InsideWood (2004)—onwards. https://insidewood.lib.ncsu.edu/searc h. Accessed 14 June 2017 
IPCC (2014) Climate Change 2014: Synthesis Report. Contribution of Working Groups I, II and III to the Fifth Assessment Report of the Intergovernmental Panel on Climate Change [Core Writing Team, R.K. Pachauri and L.A. Meyer (eds.)]. IPCC, Geneva, Switzerland. https://epic.awi.de/37530/1/IPCC_AR5_SYR_Final.pdf

Iturrate-Garcia M, Heijmans MMPD, Schweingruber FH, Maximov TC, Niklaus PA, Schaepman-Strub G (2017) Shrub growth rate and bark response to soil warming and nutrient addition-a dendroecological approach in a field experiment. Dendrochronologia 45:12-22. https://doi.org/10.1016/j.dendro.2017.07.001

Johansen BE, Karlsen SR, Tømmervik H (2012) Vegetation mapping of Svalbard utilising Landsat TM/ETM+ data. Polar Rec 48:47-63. https://doi.org/10.1017/S0032247411000647

Kurczyńska EU (2002) Epiderma wielokrotna łodyg wierzby: szczególny przypadek powtarzania fenotypu epidermalnego. Wydawnictwo Uniwersytetu Śląskiego, Katowice, Poland

Kwaśniewska E, Pereyma J (2004) Termiczne pory roku w Hornsundzie (SW Spitsbergen); Thermal seasons in Hornsund (SW Spitsbergen). Problemy Klimatologii Polarnej 14:157-169

Larson PR (1994) The vascular cambium. Development and structure. Springer, Berlin

Le Moullec M, Buchwal A, van der Val R, Sandal L, Hansen BB (2018) Annual ring growth of a widespread high arctic shrub reflects past fluctuations in community-level plant biomass. J Ecol 2018:1-16. https://doi.org/10.1111/1365-2745.13036

Li B, Heijmans MMPD, Berendse F, Blok D, Maximov T, Sass-Klaassen U (2016) The role of summer precipitation and summer temperature in establishment and growth of dwarf shrub Betula nana in northeast Siberian tundra. Polar Biol 39:1245-1255. https://doi. org/10.1007/s00300-015-1847-0

Liang E, Eckstein D (2009) Dendrochronological potential of the alpine shrub Rhododendron nivale on the south-eastern Tibetan Plateau. Ann Bot 104:665-670. https://doi.org/10.1093/aob/mcp158

Marciszewska K, Tulik M (2013) Hydraulic efficiency and safety of xylem sap flow in relation to water stress in woody plants. In: Da Silva VR (ed) Hydraulic conductivity. InTech. https://doi. org/10.5772/5665610.5772/56656

Marsz AA, Styszyńska A (2013) Climate and climate change at Hornsund Svalbard. Gdynia Maritime University, Gdynia

Migała K, Wojtuń B, Szymański W, Muskała P (2014) Soil moisture and temperature variation under different types of tundra vegetation during the growing season: a case study from the Fuglebekken catchment, SW Spitsbergen. CATENA 116:10-18. https://doi. org/10.1016/j.catena.2013.12.007

Myers-Smith IH, Elmendorf SC, Beck PSA et al (2015) Climate sensitivity of shrub growth across the tundra biome. Nature Clim Change 5:887-891. https://doi.org/10.1038/NCLIMATE2697

Myśkow E (2010) Procambium-cambium transition during vascular meristem development in Diospyros lotus. Botany 88:985-993. https://doi.org/10.1139/B10-070

Myśkow E (2014) Occurrence of atypical phellem in representatives of Cornus. Int J Plant Sci 175:328-335

Myśkow E, Tulik M (2014) Wtórne tkanki okrywające u drzew leśnych. Secondary protective tissues of forest trees. Sylwan 158:92-202

Nakatsubo T, Fujiyoshi M, Yoshitake S, Koizumi H, Uchida M (2010) Colonization of the polar willow Salix polaris on the early stage of succession after glacier retreat in the High Arctic, Ny-Ålesund, Svalbard. Polar Res 29:385-390. https://doi.org/10.3402/polar .v29i3.6078

O'Brien TP, McCully ME (1981) The study of plant structure principles and selected methods. Termarcarphi Pty Ltd, Melbourne

Opała-Owczarek M, Pirożnikow E, Owczarek P, Szymański W, Luks B, Kępski D, Szymanowski M, Wojtuń B, Migała K (2018) The influence of abiotic factors on the growth of two vascular plant species (Saxifraga oppositifolia and Salix polaris) in the High
Arctic. CATENA 163:219-232. https://doi.org/10.1016/j.caten a.2017.12.018

Owczarek P (2010) Dendrochronological dating of geomorphic processes in the High Arctic. Landf Anal 14:45-56

Owczarek P, Opała M (2016) Dendrochronology and extreme pointer years in the tree-ring record (AD 1951-2011) of polar willow from Southwestern Spitsbergen (Svalbard, Norway). Geochronometria 43:84-95. https://doi.org/10.1515/geochr-2015-0035

Pallardy S (2007) Physiology of woody plants, 3rd ed. Elsevier

Richter D, Matuła J, Pietryka M, Wojtuń B, Zwolicki A, ZmudczyńskaSkarbek K, Stempniewicz L (2018) Cyanobacterial and green algal assemblages in various tundra habitats in the High Arctic (West Spitsbergen, Norway). Acta Soc Bot Pol (in press)

Sandal L (2017) Spatiotemporal patterns of plant growth in a warming high Arctic: insights from dendrochronology of Salix polaris. MSc Thesis. Norwegian University of Science and Technology. https://brage.bibsys.no/xmlui/handle/11250/2445603

Schmidt NM, Baittinger C, Kollmann J, Forchhammer MC (2010) Consistent dendrochronological response of the dioecious Salix arctica to variation in local snow precipitation across gender and vegetation types. Arct Antarct Alp Res 42:471-475. https://doi. org/10.1657/1938-4246-42.4.471

Schreiber L (2010) Transport barriers made of cutin, suberin and associated waxes. Trends Plant Sci 15:546-553. https://doi. org/10.1016/j.tplants.2010.06.004

Schweingruber FH (1990) Anatome europäischer Hölzer - Anatomy of European woods. Eidgenössische Forschungsanstalt für Wald, Schnee und Landschaft, Birmensdorf (Hrsg), Haupt, Bern und Stuttgart

Schweingruber FH (1996) Tree rings and environment: dendroecology. Haupt-Verlag, Bern

Schweingruber FH (2007) Wood structure and environment. Springer, Berlin

Schweingruber FH, Hellmann L, Tegel W, Braun S, Nievergelt D, Büntgen U (2013) Evaluating the wood anatomical and dendroecological potential of arctic dwarf shrub communities. IAWA J 34:485-497. https://doi.org/10.1163/22941932-00000039

Skrzypek G, Wojtuń B, Richter D, Jakubas D, Wojczulanis-Jakubas K, Samecka-Cymerman A (2015) Diversification of nitrogen sources in various tundra vegetation types in the high Arctic. PLoS ONE 10:e0136536. https://doi.org/10.1371/journal.pone.0136536

Sokal RR, Rohlf FJ (2003) Biometry. Freeman and Company, New York

Spicer R, Groover A (2010) Evolution of development of vascular cambia and secondary growth. New Phytol 186:577-592. https://doi. org/10.1111/j.1469-8137.2010.03236.x

Surový P, Olbrich A, Polle A, Ribeiro NA, Sloboda B, LangenfeldHeyser R (2009) A new method for measurement of annual growth rings in cork by means of autofluorescence. Trees 23:1237-1246. https://doi.org/10.1007/s00468-009-0363-7

Szymański W, Skiba S, Wojtuń B (2013) Distribution, genesis, and properties of Arctic soils: a case study from the Fuglebekken catchment, Spitsbergen. Pol Polar Res 34:289-304. https://doi. org/10.2478/popore-2013-0017

Trockenbrodt M (1990) Survey and discussion of the terminology used in bark anatomy. IAWA J 11:141-166. https://doi. org/10.1163/22941932-90000511

von Arx G, Archer SR, Hughes MK (2012) Long-term functional plasticity in plant hydraulic architecture in response to supplemental moisture. Ann Bot 109:1091-1100. https://doi.org/10.1093/aob/ $\operatorname{mcs} 030$

Walker DA (2010) Hierarchical subdivision of Arctic tundra based on vegetation response to climate, parent material and topography. Glob Change Biol 6:19-34. https://doi.org/10.104 6/j.1365-2486.2000.06010.x 
Walker DA, Raynolds MK, Daniels FJA et al (2005) The circumpolar arctic vegetation map. J Veg Sci 16:267-282. https://doi. org/10.1111/j.1654-1103.2005.tb02365.x

Węgrzyn M, Wietrzyk P (2015) Phytosociology of snowbed and exposed ridge vegetation of Svalbard. Polar Biol 38:1905-1917. https://doi.org/10.1007/s00300-015-1751-7

Weijers S, Buchwal A, Blok D, Löffler J, Elberling B (2017) High Arctic summer warming tracked by increased Cassiope tetragona growth in the world's northernmost polar desert. Glob Change Biol 23:5006-5020. https://doi.org/10.1111/gcb.13747

Weil RR, Brady NC (2017) The nature and properties of soils, 15th ed. Pearson
Wodzicki TJ (2001) Natural factors affecting wood structure. Wood Sci Technol 35:5-26. https://doi.org/10.1007/s002260100085

Woodcock H, Bradley RS (1994) Salix arctica (Pall.): its potential for dendroclimatological studies in the high Arctic. Dendrochronologia 12:11-22

Publisher's Note Springer Nature remains neutral with regard to jurisdictional claims in published maps and institutional affiliations. 